\title{
ASPECTOS DEL REACCIONARISMO ESPAÑOL
}

JUAN RICO

Universidad de Alicante

El tema del carácter humano ha sido, desde siempre, central en la reflexión intelectual, ya sea desde el punto de vista de la filosofía, de la teología, la astrología, la política, la historia o el derecho. Sin embargo, no ha sido hasta recientemente, es decir, hasta la puesta de largo de la psicología como ciencia, que ha pasado a ocupar un lugar importante entre los conceptos de las ciencias sociales modernas, teniendo que atravesar el proceso, como la propia psicología, que va de lo individual a lo social o colectivo. Así, entre los pioneros de la actual ciencia psicológica, Jung, desviado ya de Freud, se atreve a publicar sus Tipos psicológicos ${ }^{1}$, sin salirse de lo individual, pero dando un importante paso contra las reticencias cientifistas oficiales, que soslayaban sumergirse en tan espinoso tema. Freud, desde luego, escribiría su Psicoanálisis de las masas ${ }^{2}$, abriendo así el camino a actitudes y estudios más radicales, como la Psicología de masas del fascismo ${ }^{3}$, del atormentado y genial Reich, o, con tintes más sociológicos, las reflexiones de Fromm, Marcuse, Adorno, W. Mills, etc., que han intentado, asimilando tanto a Marx como a Freud, analizar los rasgos caracteriológicos y mentales del hombre occidental. Arbol que acabaría generando la rama de la psicología social, como hoy se denomina a una

1 Barcelona, 1971, 2 tomos.

2 Obras completas, tomo VII, Madrid, 1974.

3 Madrid, 1972. W. ReıCH, también escribió un Análisis del carácter (traducido por Edit. Paidós de Buenos Aires). 
disciplina muy cultivada en los países más "desarrollados" y casi desconocida en otros, como el nuestro, salvo algunas cátedras universitarias de pane lucrando.

Así pues, no partiendo de la psicología social, no resulta fácil, desde un punto de vista riguroso, atreverse con el estudio de los caracteres diferenciales de una comunidad. Si, además, se quiere analizar y comprender los caracteres "nacionales", el problema se complica, en primer lugar, porque lo "nacional", bajo su homogeneidad política, casi siempre esconde diferencias sociológicas, históricas, étnicas o, incluso, lingüísticas. Ello es evidente en el caso de España, donde aún hoy no se ha llegado a un acuerdo sobre qué sea eso de ser "español». No vamos a entrar nosotros en esa polémica, respetable y tal vez necesaria ${ }^{4}$. Tan sólo queremos iniciar nuestra propia reflexión removiendo un poco las brasas.

Para ello nos hemos valido básicamente de la historia y de la literatura "histórica»: documentos de primera mano; opiniones de contemporáneos a los hechos-tipo; generalizaciones de pensadores e intérpretes de nuestro devenir comunitario, y aproximaciones a nuestra realidad social desde perspectivas literarias o extracientíficas.

El método aplicado ha de ser, pues, el propio de la historia, ya que se trata de describir actitudes caracteriológicas ocurridas en el pasado y desplegadas en torno a acontecimientos "históricos", es decir, significativos en el devenir comunitario de nuestra nación, cual son el final del Antiguo Régimen, la Guerra de la Independencia y el Trienio constitucional.

A partir de la crisis del efímero y ambiguo despotismo ilustrado de Carlos III y Carlos IV, efectivamente, está abierto en Es-

4 Como ejemplos de tal preocupación, rémitimos a la ya célebre polémica entre SÁNCHEZ AlBornoz y Américo CASTRO y sus seguidores, o a las posturas de los integrantes en la llamada "generación del 98", al regeneracionismo, a ORTEGA, etc. Nosotros, por perspectiva y por método, preferimos posturas como la de Brenan (El laberinto español, París, 1962), Julián MARías (Los españoles, Madrid, 1971, 2 t.), BenNassar (Los españoles, Barcelona, 1978), o MARAVALL (Sobre el mito de los caracteres nacionales, Revista de Occidente, núm. 3, junio de 1963). 
paña el dilema de seguir el destino de Europa - para lo que era preciso racionalizar y modernizar todas las esferas de la vida económica y social, incluida la forma política-, o bien de aferrarse a nuestras propias tradiciones que, según sus ideólogos ${ }^{5}$, se resumían en la forma barroca del "Altar y el Trono": rey absoluto y todopoderoso "por la gracia de Dios", Iglesia omnipresente en la dirección moral del pueblo -con la Inquisición como supremo instrumento corrector - y pueblo obediente e ingenuo, es decir, ignorante de las "novedades", consideradas perniciosas para su alma pueril.

Para estos últimos, el pueblo español era esencial y decididamente diferente del francés, del inglés, etc., y diferentes eran su forma de ser y trabajar, su sentido del honor y, sobre todo, su religión. Y ello no se debía a otra circunstancia que a la voluntad divina: Dios nos había hecho así porque así quería que fuésemos y pretender ser diferentes era como ir contra los designios fatales de la Divina Providencia. Todo ello, además, valorado muy positivamente, como si el español católico y montaraz, el don Pelayo, fuera el elegido por Dios para descubrir y evangelizar al mundo con la religión verdadera; discurso reaccionario adornado con una profusa parafernalia, barroca e irracional, dirigida no tanto a convencer como a atemorizar, con el fin de sostener una situación que a todas luces hacía aguas, menos, sin embargo, de lo que hubieran querido los progresistas españoles, demasiado inflamados del optimismo kantiano, primero, y del utopismo revolucionario, después.

Porque el hecho - que nos Ilamó la atención desde el interés por nuestra historia moderna y contemporánea-, es que, por debajo de las interpretaciones partidistas y esquemáticas, con más o menos buena fe, se soslayaba casi siempre la referencia - no digamos el análisis detenido- a la actitud y el comportamiento del pueblo ante acontecimientos históricamente decisivos. Como si diera un poco de vergüenza reconocer, por ejemplo, el importante papel del pueblo español en el fracaso

5 Una buena aproximación resulta el libro de Javier HERRERo, Los orígenes del pensamiento reaccionario español, Madrid, 1971. 
del primer constitucionalismo nacional en la persecución, delación y exilio de afrancesados y liberales y, sobre todo, en la drástica implantación del gobierno reaccionario de Fernando VII. Como si, en definitiva, el pueblo llano hubiera sido indiferente a los grupos mentores, promotores y abanderados del fenómeno real -y también mito-de las "dos Españas", un fenómeno que aparece en el escenario de nuestra historia nacional con la relativa frustración del despotismo ilustrado carlotercerista y sobrevive - más o menos dramáticamente- hasta nuestros días.

En el presente trabajo, pues, nos interesa más describir el papel jugado por esas actitudes reaccionarias del pueblo llano en el desarrollo de sucesos históricos importantes, que analizar el origen o causas de las mismas, es decir, soslayamos conscientemente el planteamiento de Farrington de

aclarar si superstición popular significa forzosamente superstición nacida del pueblo o más bien superstición impuesta al pueblo ${ }^{6}$.

sin perder de vista, desde luego, que una cabal descripción implica correspondientes juicios de valor, tanto en quien escribe como en quien lee.

\section{EL ANTIGUO REGIMEN}

Uno de nuestros más lúcidos y concienzudos historiadores, J. A. Maravall, no podía, en efecto, ignorar el tema que nos ocupa, máxime si tenemos en cuenta su filiación intelectual, próxima a Ortega y a los grupos de tendencia liberal que recogen críticamente el viejo problema sobre la identidad de España y los españoles. $Y$ de esta manera, como estudioso de nuestra llustración, aporta su saber en un artículo Sobre el mito de los caracteres nacionales ${ }^{7}$, en donde parte de la tesis de que

las imágenes de los pueblos, aparentemente fijas y determinadas, son algo circunstancial, transitorio y modificable,

${ }^{6}$ Ciencia y política en el mundo antiguo, Madrid, 1973, pág. 11.

7 Op. cit., págs. 262-263. 
en un encomiable intento de racionalizar lo mítico, es decir, de entender y expresar científicamente aquello que es susceptible de ser manipulado dogmáticamente con fines políticos casi siempre inmovilistas e interesados y que no es más que expresión coyuntural y móvil de la historia.

En cualquier caso, el tema de los caracteres nacionales surge modernamente en la conciencia europea al pairo de la preocupación por la historia nacional, de ahi que también constituya una preocupación constante entre nuestros ilustrados:

la fuerza social de los estereotipos de un pueblo, sobre sí mismo y sobre los demás, es cada vez mayor a partir del momento en que granan las modernas naciones. En los siglos XVIII y XIX, los problemas políticos, económicos, sociales, las interpretaciones históricas, etc., se presentan como determinadas por el carácter que a cada pueblo corresponde. Basta ver cómo la polémica sobre la cultura española en el siglo XVIII, sobre todo en Cadalso y en Masdeu..., se presenta como un problema de "carácter", cualquiera que sea la formulación que uno y otro le den ${ }^{8}$.

Lo que Maravall dice de Cadalso y Masdeu vale también para otros ilustrados: Francisco Fernández Navarrete lee la primera disertación de la Academia Española, en 1738, bajo el título Sobre el carácter de los españoles; Sempere y Guarinos hace continuas referencias en su variada obra a la "superstición" y al "bartolismo" como los vicios de los españoles que oponen mayores obstáculos al progreso y desarrollo de la nación; León de Arroyal, en Pan y toros, arremete contra desidia y holgazanería del pueblo, alimentada desde el poder, con amarga desesperación, etcétera.

La modernidad de los autores ilustrados, que no habían conseguido emanciparse del todo de los residuos mentales miticos del pasado feudal, estriba, no obstante, en la consideración coyuntural o "histórica" que hacen de situaciones y actitudes colectivas. Con ello demuestran, en primer lugar, su talante progresista, la aceptación de que la historia de las comunidades es acumulativa en un sentido de mejora gradual y, en segundo lugar, que el instrumento más eficaz para apoyar esa mejora es la educación. De ahí que las consideraciones sobre el atraso,

8 Ibíd. 
la decadencia, la superstición, el carácter colectivo reaccionario, estén siempre relacionados por ellos con la ignorancia y la falta de instrucción adecuada. Aunque la mayoría de los ilustrados, desde Voltaire a Jovellanos, desconfía del pueblo, ninguno pierde la esperanza de que con el bálsamo de la instrucción pública - paternalista y autoritaria, según la entienden-, podrán convertir a la masa supersticiosa e ignorante en honrados y trabajadores ciudadanos.

¿Pero quién era, en realidad, ese pueblo a fines del XVIII y cuáles sus atributos? Salvo algunas variaciones de las consideradas idiosincrásicas, las masas populares de toda Europa ofrecían los mismos rasgos. Veamos cómo era el pueblo francés en los aledaños de la revolución burguesa:

\begin{abstract}
Mentalmente..., marcado por una mezcla de lo maravilloso con el fervor cristiano, un frecuente analfabetismo, una vida local atomizada, una concepción débil o nula del Estado, de la nación, de la patria, excepto la adoración del monarca o la presencia física del peligro. Es el tiempo de los dialectos y de las brujas, de los pastores y de los molineros, de los señores y los diezmos, de los consumeros y los sargentos, de las estaciones y los signos del zodiaco, con el rey y Dios inaccesibles, supremos jueces, supremos recursos y consolaciones... La base de la sociedad representa las relaciones de una masa de dominados con un puñado de dominadores $^{9}$.
\end{abstract}

En España, como en el resto de Europa, la masa popular era un conglomerado heterogéneo compuesto por campesinos pobres, trabajadores de las ciudades y un gran número de pobres -140.000, según Campomanes - y pícaros difícil de determinar. Podemos homogeneizarlos a todos ellos, aparte de su atraso mental, bajo un mismo atributo, el de la menesterosidad, alimentada con la transformación del régimen feudal:

La menesterosidad del pueblo en el siglo XVIII se agrava con la enajenación de los bienes comunales y con el surgimiento de una industria exigente de mano de obra... La calidad menesterosa, si no la de indigente, se une así, para oprobio del régimen social que imperaba, con la circunstancia de afectar a los más, de ligarse a ese mayor número al que se va empezando a tomar en consideración ${ }^{10}$.

9 Hubert Methivier, L'Ancien Régime en France, París, 1981, pág. 21.

10 J. BeNEYTo, Historia social de España e Hispanoamérica, Madrid, 1973, página 313. 
Puesto que el relativo desmoronamiento del régimen vinculativo feudal no llevó aparejado en España el necesario desarrollo del modo de producción capitalista y, además, pervivió en toda su fuerza el poder de la Iglesia sobre las creencias populares, nos encontramos con una mayoría de la población pobre y analfabeta, que para sobrevivir no para mientes en recurrir a la picaresca, la mendicidad casi institucionalizada y la vinculación servil-feudal más o menos encubierta. Quizá este sostenimiento de los medios de subsistencia tradicionalès, no sometidos a regulación laboral y en muchos casos más productivos que los derivados de un salario medio - muy bajo en relación al coste de la vida-, expliquen en parte las posturas reaccionarias o defensoras del antiguo régimen de buena parte de esta masa popular que no captaba las ventajas utilitarias, proclamadas por los ilustrados, del trabajo regularizado y "productivo". De ahí que pueda hablarse de esta parte de la población española como lo hace Méndez Bejarano:

La masa popular, religiosa e inculta..., vivia en absoluto alejada de la política, creía sinceramente las enseñanzas ortodoxas, no sin adulterarlas con cierto fatalismo de abolengo musulmán y copiosa levadura de viles supersticiones; se dejaba arrebatar por invencible propensión a lo maravilloso, y alentaba satisfecha de sentirse española. Nuestro pueblo no dudaba un momento de la superioridad nacional. Los extranjeros le parecían seres más imperfectos, hombres inferiores y, quién sabe, de haber conocido el darwinismo, si los hubiera juzgado tipos de transición.

La preocupación popular añeja suponía enlos judíos un miembro o apéndice que sólo tienen los animales, y para el vulgo ignorante, era judío todo hombre no cristiano o no católico.

$Y$ a tal efecto ascendía el desconocimiento de la realidad, que la gente se sorprendia de que los extranjeros hablasen sus incomprensibles jerigonzas, pudiendo "hablar en cristiano", en un idioma "tan claro y natural" como la lengua española ${ }^{11}$.

Era lógico que esta forma de ser española, retrógrada y tradicionalista, que suponia un serio obstáculo a las «luces" y a la modernización del país, según los modelos extrapirenaicos aceptados por los ilustrados, constituyera una constante preocupación de éstos. El caso de José Cadalso deplorando la inamovilidad secular del carácter de gran parte de los españoles de

11 Méndez Bejarano, Historia política de los afrancesados, Madrid, 1912, páginas 24-25. 
su tiempo, resulta significativo. Oigamos su diagnóstico, contenido en sus célebres Cartas marruecas:

No me parece que mi nación está en el estado que infieres delas cartas de Gazel, y según él mismo lo ha colegido de las costumbres de Madrid y alguna otra capital. Deja que él mismo te escriba lo que notare en las provincias, y verás cómo de ellas deduce que la nación es hoy la misma que era tres siglos ha. La multitud y variedad de trajes, de costumbres, lenguas y usos es igual en todas las cortes por el concurso de extranjeros que acude a ellas; pero las provincias interiores de España, que por su poco comercio, malos caminos y ninguna diversión, no tienen igual concurrencia, producen hoy unos hombres compuestos de los mismos vicios y virtudes que sus quintos abuelos. Si el carácter español, en general, se compone de religión, valor y amor a su soberano, por una parte, y por otra de vanidad, desprecio a la industria (que los extranjeros llaman pereza) y de masiada propensión al amor; si este conjunto de bienes y malas cualidades componían el carácter nacional de los españoles cinco siglos ha, el mismo compone el de los actuales ${ }^{12}$.

Al menos matiza Cadalso las excepciones de la corte madrileña, por ser ésta como las demás europeas -él había viajado y había visto-, y las provincias litorales, más avanzadas por su comercio y consiguiente red de comunicaciones modernas; planteando, en consecuencia, un problema que. llega casi hasta nuestros días: el del atraso y subdesarrollo de la España interior. Pero si para Cadalso el problema del carácter colectivo tiene ya más que ver con la existencia -circunstancial, geográfica, histórica, económica-, que con la esencia del pueblo español, mucho más radical resulta el análisis de un León de Arroyal, que en su agria y acusadora Oración apologética en defensa del estado floreciente de España, más conocida como Pan y toros —difundida anónimamente entre 1793 y 1796_; arremete sin piedad, en un tono cáustico y descorazonado, contra lo que considera las verdaderas causas de ese carácter reaccionario del pueblo:

Me ha presentado una España muchacha, sin instrucción y sin conocimientos; un vulgo bestial; una nobleza que hace gala de la ignorancia; unas escuelas sin principios; unas universidades fieles depositarias de las preocupaciones de los siglos bárbaros; unos doctores del siglo $\mathrm{X}$ y unos premios destinados a los súbditos del emperador Justiniano y del papa Gregorio IX. La ciudad metrópoli tiene más templos que casas, más

12 Madrid, 1970, cartas XX y XXI, págs. 62-66. 
sacerdotes que seglares, y más aras que cocinas... Me ha mostrado una España decrépita y supersticiosa, que pretende encadenar hasta las almas y los entendimientos. La ignorancia ha engendrado siempre la superstición, así como la soberbia la incredulidad.

Las fiestas de toros son los eslabones de nuestra sociedad, el pábulo de nuestro amor patrio y los talleres de nuestras costumbres políticas. ...ellas proporcionan hasta el bajo pueblo la diversión y la holganza, que es un bien; y le impiden el trabajo y la tarea, que es un mal...

¿Quién, admirando la subordinación de un pueblo inmenso, a quien (en la ocasión en que se le concede más libertad) se le presenta el verdugo que el amenaza con los azotes de la esclavitud, podrá extrañar después la opresión del ciudadano? ¿Quién podrá dudar de la sabiduría del gobierno, que para apagar en la plebe todo espiritu de sedición la reúne en el lugar más apto para todo desorden?... ¿Quién no deleitará con la concurrencia de un gentío innumerable, mezclados los dos sexos sin ningún recato, la tabernera con la grande, el barbero con el duque, la ramera con la matrona y el seglar con el sacerdote; donde se presenta el lujo, la disolución, la desvergüenza, el libertinaje, el atrevimiento, la estupidez, la truhanería y, en fin, todos los vicios que oprobian la humanidad y la racionalidad, como el solio de su poder?... ¿Quién no conocerá los innumerables beneficios de estas fiestas? Sin ellas, el sastre, el herrero y el zapatero pasarían los lunes sujetos al improbo trabajo de sus talleres...; los magistrados (carecerían) de medios de embotar y adormecer toda idea de libertad civil... En estas fiestas todos se instruyen...; admira el político la insensibilidad de un pueblo que aquí mismo, tratado como esclavo, jamás ha pensado en sacudir el yugo de la esclavitud, aún cuando la inadvertencia del gobierno parece lo pone en estado de sacudirle... si Roma vivía contenta con pan y armas, Madrid vive contento con pan y toros. Los tétricos ingleses, los franceses volterianos pasan los días y las noches entre el estudio ímprobo y las peligrosas disputas de la política, y apenas después de muchos meses de contrariedades acuerdan una ley; los festivos españoles las pasan entre el agradable ocio y las deliciosas funciones, y en un instante se hallan con mil leyes acordadas sin contrariedad de ninguno... ¡Feliz España! ¡Feliz patria mia, que asi consigues distinguirte de todas las naciones del mundo!... iFeliz tú, que contenta con tu estado no envidias al ajeno $y$, acostumbrada a no gobernar, obedeces a todos!... Sigue, sigue esta ilustración y prosperidad para ser como eres, el non plus ultra del fanatismo de los siglos... Haya pan y toros, y más que no haya otra cosa. Gobierno ilustrado, pan y toros pide el pueblo. Pan y toros es la comidilla de España. Pan y toros debes proporcionarle para hacer en lo demás cuanto se te antoje in secula seculorum. Amén ${ }^{13}$.

Difícilmente puede expresarse mayor cantidad de impotencia y amargura rousseaunianas ante los "males de la patria", como reclamarían más tarde Lucas Mallada y los regeneracionis-

13 Edición de Antonio Elorza, Pan y toros y otros papeles sediciosos, Madrid, 1971 , págs. 24 y ss. 
tas. Y es que Arroyal, un hombre que conocía muy de cerca los vericuetos de la política y, sobre todo, los problemas de la España rural, y que había sido uno de los pocos críticos escépticos del mejor despotismo ilustrado ${ }^{14}$, veía ahora sus temores actualizados, tanto en la actitud contrarrevolucionaria del gobierno y la Iglesia - desde los sucesos de Francia-, como en la irracional xenofobia popular.

En lo referente a este último aspecto, que tomará dramáticas proporciones en la guerra de la Independencia, no estará de más recordar algunos de los motivos de la francofobia española, derivados de la larga presencia francesa en nuestro suelo, tal como expone Bartolomé Bennasar en uno de sus espléndidos trabajos:

Recientes estudios han demostrado que la afluencia de mano de obra francesa alcanzó también al reino de Castilla. En 1665, los franceses representaban alrededor del $15 \%$ de la clientela de los doscientos cuarenta albergues madrileños que figuraban en el registro de ese año. Y casi todos eran trabajadores de muy modesta categoría: buhoneros, aguadores, afiladores, etc. En esos mismos años, Francisco Martinez de la Mata señalaba que ciento veinte mil extranjeros, franceses en su mayoria, realizaban en España las tareas efectuadas antaño por los moros... En Andalucía, cuya decadencia fué más tardía, tal situación perduró hasta fines del siglo XVIII ${ }^{15}$.

Independientemente de la gran dificultad para medir el alcance real de tales fenómenos en la mitología y los tópicos populares, parece indudable la influencia de los mismos en el comportamiento de los sectores reaccionarios, no sólo ante los franceses invasores, sino, por extensión, ante los españoles sospechosos de afrancesamiento que, a partir de 1808, se convirtieron

14 Véase el estudio introductorio del mismo EloRza a las Cartas politico-económicas al conde de Lerena, de ArRoYAL, Madrid, 1968.

15 Los españoles, op. cit., pág. 100. Un hombre público como MacANaz parece participar del sentimiento general al escribir sus Males y daños que han ocasionado a la España muchos extranjeros, que entre 1788 y 1789 se intentó editar y no se censuró siquiera "por orden del Rey" (FERNÁNDEZ DURO, Catálogo de censuras de obras manuscritas pedidas por el Consejo a la Real Academia de la Historia antes de acordar las licencias de impresión, Bol. de la R. Acad. de la H., núm. 35, noviembre de 1899, pág. 404). 
para aquéllos en los traidores y antipatriotas por antonomasia. Mucha de esa animosidad percibieron ya los ilustrados carloterceristas ante dos fenómenos: uno, la cuestión del teatro y su modernización, y otro, más ruidoso si cabe, la polémica desencadenada por Masson de Morvilliers acerca del papel de España en la cultura europea.

En el primer caso, se desencadena una denodada lucha entre los ilustrados reformadores de la escena - con Moratín y el conde de Aranda a la cabeza- y los gustos de los espectadores, quienes, al parecer,

no se cansan del antiguo repertorio teatral de Lope y Calderón, a pesar de los anatemas que contra ellos lanza don Nicolás Fernández de Moratin. Este autor dice que las obras teatrales de Lope y Calderón son escuela de maldad, espejo de libertinaje, ejemplo de desobediencia, de improperios, de mala conducta y de picardia ${ }^{16}$.

$Y$ no se crea que nos estamos refiriendo a un tipo de teatro cortesano y elitista, sino a las representaciones a las que -buena costumbre española - acudian, mezclándose como en los toros, miembros de todos los grupos sociales y estamentos:

Todas las clases sociales son entonces entusiastas y apasionadas por el teatro. En las salas de espectáculos la gente fuma durante la representación, nadie se quita el sombrero, los actores son interpelados a voces y las mujeres de los palcos oyen toda clase de gritos, lanzados desde la "cazuela" o patio de butacas.

Sólo un autor contemporáneo es del agrado de este público tan adicto al viejo repertorio: don Ramón de la Cruz, inventor del sainete.

El carácter altivo e independiente de los hombres y mujeres del pueblo, la animosidad que les inspira todo lo extranjero, su indómita arrogancia y escasa instrucción, hacen de ellos el elemento activo que con mayor impetu y eficaciaa lucha, veinte años después de morir Carlos III, contra la invasión napoleónica ${ }^{17}$.

En realidad, el problema residía en el hecho de que el público del teatro preferia las piezas que le motivaban emocionalmente más que las frías, neoclásicas y pedagógicas que trataban de imponer los ilustrados. Si, además, éstas debian su he-

16 Tapia Ozcariz, Carlos III y su época, Madrid, pág. 380.

17 Ibíd., pág. 382. 
chura al patrón francés, tanto mejor para rechazarlas con pateos y algaradas públicas, si era preciso. Desde luego, hoy probablemente todo el mundo inclinaría, en esto del teatro, sus simpatías por aquel público bullicioso y xenófobo.

Por su parte, la polémica sobre la cultura española desencadenada por Masson, desborda el presente trabajo y es, además, suficientemente conocida ${ }^{18}$.

Tales son, a modo aproximativo, algunas de las tendencias que explican la actitud antiprogresista de buena parte del pueblo español —desde luego, orquestadas interesadamente desde arriba - que se desarrolla a partir de $1789 \mathrm{y}$, sobre todo, desde que Napoleón invade nuestro suelo. El comportamiento de tales grupos ante el favorito Godoy, en el umbral de la acción independentista, resulta un preámbulo más que ejemplar de lo que ocurriría inmediatamente, así como en los treinta años subsiguientes.

\section{GUERRA DE LA INDEPENDENCIA-LIBERALISMO DE CADIZ}

La fina imaginación y la erudición histórica de un novelista como Pérez Galdós, convierten sus Episodios nacionales en una amenísima fuente documental sobre nuestro pasado. Muchas son las alusiones acerca de la actitud reaccionaria popular, magistralmente vertidas en tipos y situaciones. Veamos cómo describe la animadversión popular contra Godoy en los inicios de la revuelta antifrancesa:

... Hijo mío, me parece que veo la corona de España paseada por los patanes y los majos en la punta de sus innobles garrotes.

Llegamos al cuartel, cuya puerta estaba bloqueada por el populacho. Don Celestino se abrió paso difícilmente. Algunos preguntaron con sorna: - ¿A dónde va el padrito?" y él, dando codazos a diestra y siniestra, repetía: - ¿Quiero ver a ese desgraciado, mi amigo y bienhechor".

18 Entre otros, trata el tema con lucidez J. MARiAs, La España posible en tiempos de Carlos III, Madrid, 1963, págs. 47 y ss. 
Muy mal recibidas fueron estas palabras; pero al fin, más que la exaltada pasión pudo el tradicional respeto que al pueblo español infundian los sacerdotes.

La turba se amansó, y don Celestino pudo abrirse calle por entre dos filas de garrotes, navajas, escopetas, sables y puños vigorosos, que se apartaban para darle paso ${ }^{19}$.

O la siguiente versión del drástico y espontáneo método empleado para prender a los sospechosos, contenida en otro episodio:

...diciéndolo, vi que entraban hasta media docena de alguaciles, asistidos de otros tantos soldados, y tras ellos una multitud de personas del bajo pueblo, todos los que a la salida bullían en la taberna, muchas mujeres de la vecindad y el contingente completo de la chiqueria de la calle. Vociferaban, gruñian, chillaban y reían en bestial coro.

Una aprehensión en aquellos tiempos no era gran novedad, pero por viejo y gastado que el asunto fuese, siempre tenia irresistibles encantos para el pueblo, que estaba muy soliviantado entonces y enfurecido contra todo lo que a liberal o afrancesado trascendiera ${ }^{20}$.

Resulta evidente la carga implícita de condena y reprobación, propia de un conspicuo liberal como Galdós, hacia las excentricidades y violencias de la plebe.

Ciñéndonos ahora a documentos estrictamente historiográficos, y para el siguiente período, valga un testimonio policial, la Comunicación de 11 de mayo de 1814, que el jefe político de Granada dirige al secretario de Estado, en la que da cuenta de la existencia en la ciudad de "algunos ciudadanos inquietos" que, entre otras manifestaciones antiliberales, habian intentado

arrancar de su sitio la lápida que existe en la plaza de la Constitución ${ }^{21}$, la que, en efecto, seis días más tarde, el 17, luego de una multitudinaria manifestación callejera, encabezada por personalidades afectas al antiguo régimen, fue derribada y sustituida por otra con el nombre de "Real Plaza de Fernando $7 .{ }^{\circ}$ ", todos los actos coreados por el grito de guerra,

El 19 de marzo y el 2 de mayo, Madrid, 1981, pág. 78.

20 Memorias de un cortesano de 1815, Madrid, 1976, pág. 79.

21 Archivo Histórico Nacional (A. H. N.), Consejos, leg. 11811. 
Viva el rey, viva la Religión y destrúyase la lápida de la Constitución con el libro infame donde está escrita ${ }^{22}$.

En el acto, como ocurrió en muchos otros sitios, es sustituido el jefe político por pronunciamiento popular. El nuevo, un militar realista, sigue informando a Madrid acerca de los acontecimientos y de la actitud reaccionaria del pueblo granadino, que exigió la inmediata destitución de todos los funcionarios públicos considerados "desafectos" al antiguo régimen y que las vacantes fueran ocupadas por otros "patriotas", que allí mismo se eligió. Hasta qué punto el pueblo - más o menos inducido, claro está-, tuvo poder en los cambios reaccionarios, lo prueban las comunicaciones del jefe político, que no se atreve a cumplir una orden real, según la cual, en principio y provisionalmente, se mandaba restituir en sus puestos a todos los funcionarios y autoridades "constituidas". En cualquier caso, no parece que este tipo de desobediencias desagradaran a las autoridades realistas ni a Madrid, que asi veían reforzado su reaccionarismo ante las espontáneas depuraciones de liberales y afrancesados que en todas partes se estaban llevando a cabo.

Retrospectivamente, hemos de ver también tales acontecimientos como atenuantes del partidismo pro-bonapartista de muchos españoles que, hasta la invasión francesa, habían dedicado sus esfuerzos en el empeño de europeizar y modernizar el pais. En efecto, si para estos reformadores se trataba de continuar el proceso de modernización constitucional-política de España, aunque eventualmente fuera según patrones extraños, o de regresar al pasado absolutista e inquisitorial; el mal menor resultaba claro y la elección también. Por esa razón, todos ellos fueron blanco de las iras de la reacción con tanta fuerza como si fueran propiamente franceses. Oigamos a este respecto las amargas quejas de una de las víctimas, Joaquín Lorenzo Villanueva, que había sido diputado en Cádiz:

Hasta por las noches iban a las cárceles a diferentes horas, tropas de mujeres cantando versos mezclados con insultos...23.

22 Ibid.

23 Apuntes sobre el arresto de los vocales de Cortes, Madrid, 1814, pág. 10. 
Igualmente deplora Villanueva las arremetidas que la prensa realista lanzaba contra los "traidores", a quienes consideraba

como enemigos, no sólo de la soberbia, sino de la sagrada persona del rey, como refractarios de nuestra santa religión, como destructores del gobierno monárquico. Anticipándose a publicar tan horribles calumnias el P. fr. Agustín de Castro, monje del Escorial, predicador del rey, autor de la Atalaya de la Mancha, el cual..., en una lista que añadió de los presos, parece que designaba al pueblo las victimas que debia sacrificar su furor ${ }^{24}$.

Parece evidente, pues, que los "afrancesados" y los primeros liberales de Cádiz habian de seguir desconfiando de ese pueblo -o vulgo, como le llamaban -, al que diferenciaban del ciudadano (instruido, honrado, industrioso, elector), y del que, sin embargo, tenían tanto que temer, mientras continuara sumido en la "ignorancia y superstición". La Gaceta de Málaga, de 24 de enero de 1812, profetizaba retóricamente el peligro del populacho para el progreso, por su obstinada desobediencia de las decisiones de las Cortes constitucionales:

¡Oh, infelices ciudadanos, cuya vida y honor penden del grito de un vulgo frenético e ignorantísimo ${ }^{25}$.

\section{TRIENIO LIBERAL (1820-23) Y SEGUNDA REACCION FERNANDINA}

La restauración de la constitucionalidad liberal en 1820 , tras seis años de persecución y represión reaccionaria más o menos despiadadas, que de todo hubo, significó un efímero y engañoso período de normalidad, desde luego más política que social. La reacción, como se demostró tres años más tarde, no hizo más que inhibir momentáneamente su rostro de los hechos públicos, pero..., para atrincherarse y conspirar con más fuerza en la sombra. Por otro lado, el conjunto de valores y creencias inducido en el pueblo durante generaciones y exacerbado duran-

24 Ibid., pág. 11.

25 A. H. N., Estado, leg. 3095-1. ${ }^{\circ}$ 
te la guerra de la independencia y sus secuelas, no podía ser cambiado en pocos años, y mucho menos a golpe de decretos. Así lo vieron algunos contemporáneos lúcidos, como Blanco White, para quien

\begin{abstract}
cuando los pueblos son infelices sin conocerlo, cuando el mayor número está creído en que nació para obedecer ciegamente, para trabajar sin gozar de nada, para vivir como por la compasión de otros; en una palabra, cuando un pueblo apenas se atreve pensar en que es esclavo y miserable, ponerlo en una conmoción política es como causar a un hombre extenuado una calentura ardiente; o buscando por otro aspecto la semejanza, es hacer correr a un ciego por entre precipicios ${ }^{26}$.
\end{abstract}

Irritado y anonadado por la brutalidad colectiva, Blanco acabó llamando "muchedumbre odiosa" a la que aclamaba y exaltaba religiosamente la vuelta del "Deseado" y la restauración del Santo Oficio mientras cantaba

\title{
Murieron los Liberales \\ Murió la Constitución \\ Porque Viva el Rey Fernando \\ Con la Patria y Religión ${ }^{27}$.
}

Hemos de detenernos aquí en un fenómeno significativo que, quizá, sea también el fundamento mayor del presente trabajo: en efecto, la atención detenida sobre nuestra historia política nos muestra el gran paralelismo existente entre la consolidación de los partidos políticos en la esfera social y el desarrollo de los tópicos, proclamas y demagogias en torno al talante revolucionario o reaccionario del pueblo. Ello es así porque todos los partidos por igual, de izquierdas y de derechas, han tenido -y tienen - como uno de sus primordiales objetivos, convertir al pueblo - que es siempre la mayoría-, en comparsa (más o menos pasiva, ésa es otra cuestión) de sus respectivos programas y pretensiones políticas. Por eso el comportamiento del pueblo, en las sociedades modernas, resulta un precioso indicador del panorama político general. Véase, si no, la eficacia de los

26 "Reflexiones generales sobre la revolución española" en Antología de obras en español, edición de Vicente LLORENS, Barcelona, 1971, pág. 225.

27 María Teresa de Ory Arriaga, introducción a España, de Blanco White, Sevilla, 1982, pág. 29. 
sondeos «de opinión», previos a las elecciones, que se practican actualmente en todas las democracias.

El caso es que a los grupos políticos modernos se debe, en buena parte, la extensión, remodelación y, en algunos casos, creación de los tópicos sobre el carácter de los pueblos, que pueden reducirse a dos grandes bloques: para la izquierda -innovadora, europeísta, romántica-, el carácter del pueblo consiste en un potencial inagotable de revolucionarismo reprimido, derivado de su deseo de emancipación colectiva y de su esperanza en la justicia social futura; por el contrario, la derecha - conservadora, inmovilista, nostálgica-, ve en el pueblo el tarro de las esencias nacionales, cual son el respeto por los valores aprendidos y la conservación ritual de lo existente, a todo lo cual aquélla gusta en Ilamar «idiosincrasia». Ello explica, por ejemplo, que el "pueblo" preferido por la derecha casi siempre sea el de base rural, mientras que la izquierda se nutra mejor del proletariado urbano, mucho más desligado de las tradiciones.

Pues bien, en la medida en que hacia 1820 podía detectarse ya en España una cierta dinamización del partidismo político, pero escasamente acompañada de la equivalente remodelación social, por la exigua plataforma burguesa existente y por la preponderancia de la España campesina, encontramos allá las contradictorias situaciones políticas conocidas, que se perpetúan a lo largo de todo el siglo y bastante más acá. Una expresión de tales contradicciones es el ambiguo comportamiento popular, o mejor, ambivalente, ante acontecimientos diferentes y hasta antagónicos, como pueden apreciar los observadores:

Así pudo verse al pueblo alternativamente endiosar entusiasmado a Riego y a sus colegas en 1820 y execrarlos y escarnecerlos en 1823 a los gritos de ¡vivan las caenas!, jabajo la Constitución! Y es que, sobre las humanas pasiones, que no dejaban de empequeñecer frecuentemente la política con divisiones intestinales, se mostraba a su imaginación siempre viva y pujante la realidad histórica, constituida por la pugna titánica de todo el pasado contra todo el porvenir ${ }^{28}$.

En cualquier caso, parece que el pueblo español, cuando ha decidido tomar partido, lo ha hecho siempre tumultuosa y radi-

28 José FESSER, 1820-1920, balance de un siglo, Madrid, pág. 132. 
calmente, lo que ha sido causa de desconcierto entre politicos e intelectuales, entre propios y extraños. De ahi que desde el extranjero se haya contribuido también a alimentar tópicos, convertidos en tales al querer extraer conclusiones generales de actitudes colectivas que sólo se explican vinculadas a su propia circunstancia. Así, cuando la reacción preparaba en 1823 la campaña de los "Cien mil Hijos de San Luis",

Hasta los ministros ingleses, que conocian muy bien lo que habia sido la Peninsular War, se esforzaron por convencer a Chateaubriadn de que abandonara una expedición que podía resultar arriesgada. La realidad se encargó de desmentir a los consejeros británicos del romántico ministro de Luis XVIII, cuyos méritos se verían muy mermados por la rapidez excesiva de un éxito militar que vino a quebrantar ante los europeos nociones más o menos legendarias sobre el pueblo español y su mentalidad liberal, originadas por su comportamiento durante la Guerra de la Independencia ${ }^{29}$.

Esa actitud popular de 1823 hizo que los conservadores volvieran a la carga sobre la "idiosincrasia» tradicionalista del pueblo español. Opiniones exageradas, indudablemente, pero no tanto, creemos, como para echarlas sin más en saco roto, como siempre han hecho liberales, progresistas y revolucionarios en general:

No fueron los 100.000 franceses mandados por el Duque de Angulema los que en 1823 acabaron con la Constitución de Cádiz; fué sólo la lealtad del pueblo español y su justa aversión a las instituciones que en vez de ventajas le acarrearon gravámenes, e inquietudes en vez de reposo. Estos sentimientos se manifestaron tan simultáneamente y unánimemente, que no hubo liberal que no reconociese desde entonces lo vano de sus ilusiones patrióticas, lo impracticable de sus teorías democráticas, lo infructuoso, en fin, de toda tentativa dirigida al restablecimiento de un régimen marcado con el sello de la desaprobación general ${ }^{30}$.

Desde luego, tras 1823, el foso entre las dos Españas llegó a cavarse y ensancharse tanto, que aún hoy podemos comprobar la dificultad en ser salvado. La persecución, delación y represión de liberales (o sospechosos de), fue mayor y más refinada que

29 Luis Diez del Corral, La monarquía de España en Montesquieu, Madrid, 1973, pág. 17.

30 Javier de Burgos, Exposición dirigida a S. M. Fernando VII desde París en... 1826... sobre los males que aquejaban a España en aquella época, Cádiz, 1834, págs. $30-31$. 
en 1814-1815, y los testimonios de ello son abrumadores. Presentaremos algunos.

\author{
Un ejemplo de delación:
}

... pero el escándalo y la irritación de los buenos vasallos de S.M. llegó a lo sumo cuando vieron que habia logrado el beneficio de la purificación, y de consiguiente declarado por amante del Rey N.S., a D. Cayetano González. escribano de Cámara, hombre malo y perverso, insolente y furibundo democrático, que se ha manifestado siempre enemigo de todo lo que huele a dignidad real, que en año 1814, estando ya el Rey en Valencia repartía con profusión un papel el más alarmante y sedicioso, titulado Proclama de un labrador de Reus, por cuyo motivo fué confinado...; que durante la última época revolucionaria ha sido considerado por uno de los corifeos más exaltados y fogosos del liberalismo, que ha sido juez de hecho, miembro de la Sociedad patriótica, dos veces regidos constitucional, comunero espontaneado, sin contar otros hechos y dichos que se omiten por no cansar la atención de V.E. ${ }^{31}$

Como es natural, también hubo entonces espíritus moderados que, aunque conservadores, veían con horror las vejaciones de la represión:

El rey hizo su entrada en la capital al grito unánime de ¡Vivan las cadenas y la Inquisición!, y el régimen absoluto comenzó. Los liberales eran perseguidos como fieras feroces, y a pesar de mi contento por la vuelta de mis hermanos en el ejército del duque de Angulema, confieso que la conducta de los realistas me incomodaba y exasperaba tanto en medio de mi niñez, que en más de una ocasión tuve serios altercados, por que siempre he visto con malos ojos el encono y la persecución contra el vencido ${ }^{32}$.

Escuchemos, por su parte, un testimonio vinculado a nuestra comarca alicantina y a uno de sus eximios liberales, el villenero Joaquín María López:

Levantado el sitio de Valencia a la aproximación del ejército de Ballesteros, se retiraron los milicianos a sus casas; pero creciendo cada día los peligros y la persecución de los constitucionales, López no pudo continuar a Villena, y se unió al cuerpo del ejército de Ballesteros, en su retirada a Andalucía, del que hizo parte hasta la desgraciada acción del Campillo de Arenas, sepulcro de la causa liberal. Dispersos entonces la mayor parte de los nacionales, sufrieron penalidades sin cuento al regreso a sus hogares, acosados en todo el tránsito por el furor de los realistas de los pueblos. El frenesí de aquella reacción y el escarnio que en ella se hizo de

31 A. H. N., Consejos, leg. 11801.

32 Fernández de Córdoba, Mis memorias intimas, B. A. E., núm. CXCll, pág. 24. 
las ideas religiosas y monárquicas. cometiendo toda clase de crimenes y excesos a los gritos sacrílegos de religión y rey. cuesta dolor el recordarIo: si bien queda el consuelo de que tanta y tan atroz persecución liberalizó a casi todas las personas decentes. que se vieron hechas el blanco de las más soeces turbas. Al llegar López a su casa fué preso y conducido al cuartel realista de Novelda. que era el terror de la comarca ${ }^{33}$.

Testimonios historiográficos que en la prosa viva y perfecta de Galdós relucen con tintes dramáticos. He aquí dos secuencias de El terror de 1824, una dedicada al comportamiento de la chusma profernandista y otra en la que elabora una especie de retrato-robot del personaje reaccionario de base, entonces representado por el voluntario realista.

Cuando los carros estuvieron cerca, una voz acatarrada y becerril gritó: ; Vivan las caenas! iviva el rey absoluto y muera la nación! Respondióle un bramido infernal como si a una rompieran a gritar todas las cóleras del averno, y al mismo tiempo la luz de las hachas prontamente encendidas permitió ver las terribles figuras que formaban procesión tan espantosa...

...roncos, mojados de pies a cabeza, frenéticos, tocados de una borrachera singular que no se sabe si era de vino o de vergüenza, brincaban sobre los baches, agitando un girón con letras, una bota escuálida y un guitarriIlo sin cuerdas. Era aquello una horrenda mezcla de bacanal, entierro y marcha de triunfo. Oianse bandurrias desacordes, carcajadas, panderetazos, votos, ternos, kirieleisones, vivas y mueras, todo mezclado con el lenguaje carreteril, con patadas de animales (no todos cuadrúpedos) y con el cascabeleo de las colleras. La caravana se detuvo ante el cuerpo de guardia, y entonces aumentó el ruido. La tropo formó al punto, y una nueva aclamación al rey neto alborotó los caseríos. Salieron mujeres a las ventanas, candil en mano, y la multitud se precipitó sobre los carros ${ }^{34}$.

... Cuando de la ventana salió un hombre pequeño, doblado, de maciza arquitectura, semejante a la de esos edificios bajos y sólidos que no tienen por objeto la gallarda expresión de un ideal, sino simplemente servir para cualquier objeto terrestre y positivo. Siendo posible la comparación de las personas con las obras de arquitectura, y habiendo quien se asemeje a una torre gótica, a un palacio señorial, a un minarete árabe, puede decirse de aquél hombre que parecía una cárcel. Con su musculatura de cal y canto se avenia maravillosamente a una como falta de luces, rasgo misterioso e inexplicable de su semblante, que a pesar de tener cuanto corresponde al humano frontispicio, parecía una fachada sin ventanas. $Y$ no eran pequeños sus ojos ciertamente, ni dejaban de ver con claridad cuanto enfrente tanian; pero ello es que mirándole no se podia menos de decir: "iqué casa tan oscura!".

33 Fermin Caballero, "Vida de D. Joaquín María López" en Colección... de producciones literarias de D. ..., Madrid, 1857, t. VII, pág. 50.

34 Madrid, 1976, pág. 14. 
Su fisonomia no expresaba cosa alguna, como no fuera una calma torva, una especie de acecho pacienzudo ${ }^{35}$.

Y continúa Galdós, como un psicoanalista concienzudo, describiendo el tipo caracteriológico del reaccionario de extracción popular, cuyos atributos misteriosos reducían los progresistas cultos a la mezcla de superstición e ignorancia.

Hasta aquí hemos querido testimoniar, desde diferentes ángulos descriptivos, algunos aspectos de un problema español peliagudo y que dista mucho de haber sido resuelto, a pesar de haber mantenido en vilo - y en guerra abierta, por desgracia - a políticos, intelectuales y al propio pueblo. Desde el punto de vista de la historia, es decir, de la descripción cabal y rigurosa, el problema se resuelve más o menos, siempre y cuando se contextúe debidamente. Pero en ese caso no puede el historiador hacer más que afirmaciones del tipo: «en aquel momento y ante aquellos hechos, el pueblo reaccionó así y así, etc.". Nada más (y nada menos, dirán los optimistas) y, sin embargo, continuamos inmersos en el drama (¿nacionalismo caduco?) del ser español. ¿Y qué pueblo está libre de semejante narcisismo? Tal vez el quid de la cuestión deriva del insondable abismo - que tan bien cantó Luis Cernuda - entre la realidad y el deseo. La realidad puede describirse; el deseo, en cambio, escapa constantemente a toda generalización y, a pesar de todo, forma parte intima de la nostalgia o la utopía de los pueblos. He ahí los ingredientes del drama y la contradicción humanos. Pero no queremos acabar sin traer aquí las sugestivas palabras de nuestro filósofo nacional, Ortega y Gasset, heredero directo de regeneracionistas, liberales decimononos e ilustrados, quien, con su peculiar desenfado y su brillantez intuitiva resolvía (?) nuestros arduos problemas de identidad colectiva con cuatro palabras. Sobre el tema que rios ha ocupado asi hablaba Ortega en 1916:

No debe ovidarse que somos un pueblo moralmente enfermo. Vive el español de momento a momento, sin solidaridad consigo mismo y empuja su alma atomizada, pulverizada, como un vendaval la arenilla del desierto. Una expresión de enojo, de malevolencia o, por el contrario, de entusias-

35 Ibíd., pág. 11. 
mo y adhesión que en temperamentos normales traeria a la zaga una determinada conducta, en el español suele quedar sin consecuencias. $Y$ viceversa: la convicción de que sus palabras de, hoy no van a obligarle ante si mismo a seguir una cierta trayectoria, le permite emitir opiniones extremas y simplistas que no corresponden a su estado de espíritu de ayer o de mañana. Sería interesante -y alguna vez lo intentaré - el estudio de las perversiones psicológicas que caracterizan nuestra hora actual partiendo de esta sospecha, como working hypothese: la insolidaridad del español consigo mismo ${ }^{36}$.

36 Obras completas, tomo II, pág. 164. 